\title{
WATER QUALITY INDEX (WQI) OF SHITALAKSHYA RIVER NEAR HARIPUR POWER STATION, NARAYANGANJ, BANGLADESH
}

\author{
Rumman Mowla Chowdhury ${ }^{1}$, Adib Ashhab Ankon*2, Md Kamruzzaman Bhuiyan ${ }^{3}$ \\ 1 Assistant Professor, University of Asia Pacific, Dhaka,Bangladesh, e-mail: rumman@uap-bd.edu \\ 2 Teaching Assistant, University of Asia Pacific, Dhaka, Bangladesh, e-mail: adibankon50@gmail.com \\ 3 Research Assistant, University of Asia Pacific, Dhaka,Bangladesh, e-mail: bhuiyan8769@gmail.com
}

Received: 06 May 2021

Accepted: 01 November 2021

\begin{abstract}
The present investigation is aimed at understanding the water quality parameters and the findings of a water quality index (WQI) to assess the characteristics of the Shitalakshya River near Haripur power station, Narayanganj for five different years (2013-2018) considering monsoon, pre-monsoon, post-monsoon seasonal variations. In this study, three different methods were used to evaluate the WQI named as; Weighted Arithmetic Index Method, Canadian Council of Ministers of the Environment (CCME) WQI Method and National Sanitation Foundation (NSF) Method. Essential parameters i.e. dissolved oxygen, pH, chloride, turbidity, color, biochemical oxygen demand, total dissolved solids, Silica, Iron, electrical conductivity, Phosphate were considered for calculating the WQI. According to Weighted Arithmetic Index Method, the WQI value varied from 80 to 286 for the last five years. From the National Sanitation Foundation Method, the WQI value was found within 36 to 56 for the study duration. The WQI value was varied from 3 to 16 according to the Canadian Council of Ministers of the Environment Water Quality Index Method. Based on WQI values, the Shitalakhya river water was being classified as poor water for the above-mentioned different years. Among the different parameters, mostly turbidity, electrical conductivity, TSS, Iron were the parameters that caused the situation worst.
\end{abstract}

Keywords:Water Quality Index, Dissolved Oxygen, Total Dissolved Solids, Biochemical Oxygen Demand.

\section{INTRODUCTION}

In recent decades, The rapid growth of population and the faster pace of modernization have resulted in a massive increase in demand for freshwater (Weeks, 2020). Because of the easiest accessibility, the majority of industries are emerging alongside the river. Furthermore, The cost of transporting raw resources is substantially lower when done by water. However, because the majority of companies do not have effluent treatment facilities (ETP), their effluents are finally dumped straight into rivers without being treated. As a result, resource deterioration and pollution have progressed and continued, particularly in the area of surface water. Polluted water is a major route for disease transmission. Every year, over 1.8 million people, largely children, die in underdeveloped nations as a result of water-related illnesses (World Health Organization, 2004).

For healthy living, It is critical to have access to safe drinking and usable water (Pal et al., 2018). A sufficient quantity of clean and pure drinking water is a basic requirement for all humans. Moreover, Riverine water quality is a major concern for all users since it affects human activities as well as plant and animal life (Goyette et. al., 2016). A wide range of indices has been established to summarize water quality data in a way that is both easy to explain and understand. The Water Quality Index (WQI), which assesses water quality using computed values, is one of the most effective ways to convey water quality. Water quality is determined by its physical, chemical, and biological characteristics (Chowdhury and Hossain, 2012). The WQI is a measure that indicates the combined impact of various water quality parameters (Sahu and Sikdar 2008). The WQI is a simple and effective approach for determining the appropriateness of water. It's also a great way to get information out to concerned individuals and politicians about water performance and satisfaction. As a response, it becomes an important parameter for water quality evaluation and management (both surface and groundwater). WQI indicates the combined effect of several water quality parameters and is computed from the viewpoint of (both surface and groundwater) acceptability for human consumption. WQI was first established by Horton in 1965 and then modified by Brown in 1970.

The objective of this paper is to determine the WQI of water of the Shitalakshya River near Haripur power station, Narayanganj for five different years (2013-2018). Figure 1 shows the research region with the power plant on a topographical map. Shitalakhya is the river that is regarded as one of the feeders of the Brahmaputra, *Corresponding Author:adibankon50@gmail.com https://www2.kuet.ac.bd/JES/ ISSN 2075-4914 (print); ISSN 2706-6835 (online) 
and the river's initial flow was southwest. After then, it heads east to Narayanganj and then south to Dhaleswarinear Kalagachhiya. Near Narayanganj, the river stretches for over 110 kilometers (68 miles) and has a width of 300 meters. The Brahmaputra River was separated by the Shitalakhya River, which subsequently flowed into Dhaleshwari. Many industries and companies have sprung up along the Shitalakhya River's bank as a result of its strategic position. However, These industries do not even follow or implement wastewater and hazardous water treatment methods. As a result of the inefficient discharge method, a significant volume of hazardous and effluent has been mixed up in the Shitalakhya River. Besides, Domestic and urban runoff sludge from the Narayanganj urban regions is untreated and dumped into this river. Hence, heavy metals, as well as numerous harmful compounds, are carried out by industrial wastes and effluents, and pollution is increasing at an increasing pace day by day (WARPO, 2000).

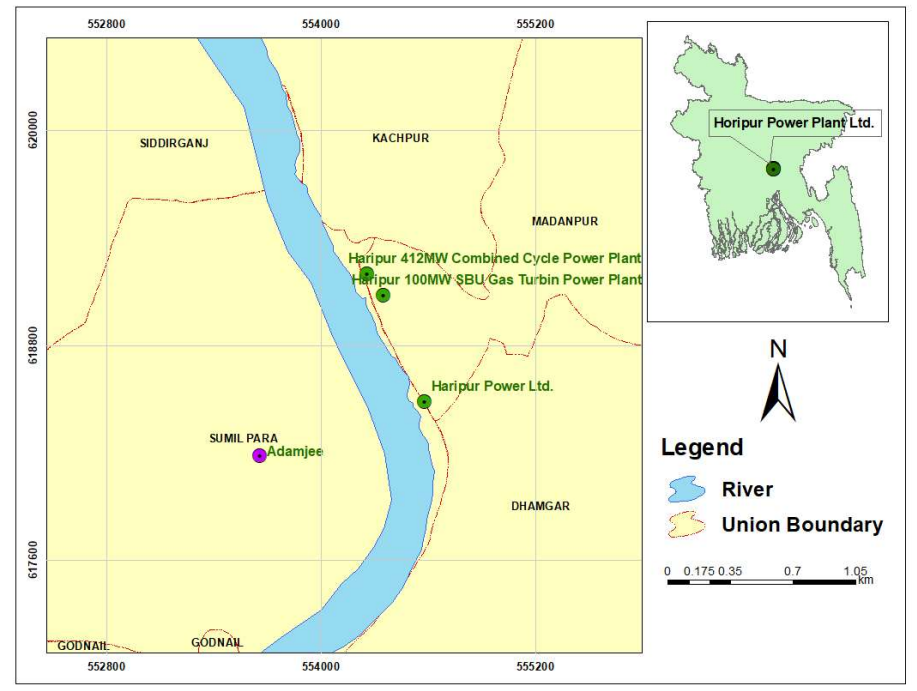

Figure 1: Location of main discharges on Sitalakhya River, Narayanganj.

Moreover, this place has been chosen by the government for establishing a power plant for electricity generation. As a result, a 412 MW Combined Cycle Power Plant was built here in 2014, and it is still operational today. Power plants need a huge amount of water for cooling purposes and therefore power plants are built beside the river. But due to the pollution over the river, power plants required extensive levels of treatment before using river water. Subsequently, this increases the cost of treatment units so the rise in the overall cost of power production affects the economy. Moreover, Local inhabitants of this area are dependent on the water of the Shitalakshya River for various purposes which made the analysis inevitable. The single value of the water quality index value will be useful for understanding the actual situation. Moreover, the trend in seasonal variation might help different stakeholders for stepping towards necessary actions. Foremost, the result might be beneficial for them to decide for treating the worst parameters especially for the time of shortage in the municipal supply water.

Several WQI's have been created and utilized correctly by government organizations and researchers throughout the years. The Index of River Water Quality, the Overall Index of Pollution, the Chemical Water Quality Index, the Iowa Water Quality Index, the Universal Water Quality Index-UWQI, the Canadian Council of Ministers of Environment Water Quality Index-CCMEWQI, and the Universal Water Quality Index-UWQI, NSFWQI is for National Sanitation Foundation Water Quality Index, OWQI is for Oregon Water Quality Index, and WAWQIM is for Weighted Arithmetic Water Quality Index Method. The CCMEWQI, NSFWQI, OWQI, and WAWQIM are the most regularly utilized of these (Oni and Fasakin,2016). The WQI was evaluated in this study using three distinct methods: The Weighted Arithmetic Index Method, the Canadian Council of Ministers of the Environment Water Quality Index Method, and the National Sanitation Foundation Method. The index results were computed using water temperature, $\mathrm{pH}$, dissolved oxygen (DO), total dissolved solids (TDS), total suspended solids (TSS), electrical conductivity (EC), hardness (Ca and $\mathrm{Mg}$ ), chloride, turbidity, alkalinity, iron, and color. 


\section{MATERIALS \& METHODOLOGY}

\subsection{Sample Collection}

Throughout the year, samples are taken from the power plant's outflow and examined the parameters (pH and Temperature) instantly at the sampling location using standard equipment.Other major water quality parameters (DO, Color, Conductivity, TDS, TSS, Hardness, Cl-, Turbidity, Alkalinity, Fe) were measured in the power plant's laboratory.

Water samples were taken once a week from Haripur (Figure 1) in Bangladesh's Narayanganj District. Except for 2017, the analysis spanned five years, from January 2013 to December 2018. The water samples were collected from the Shitalakshya River's surface water.

\subsection{Methodological Approach}

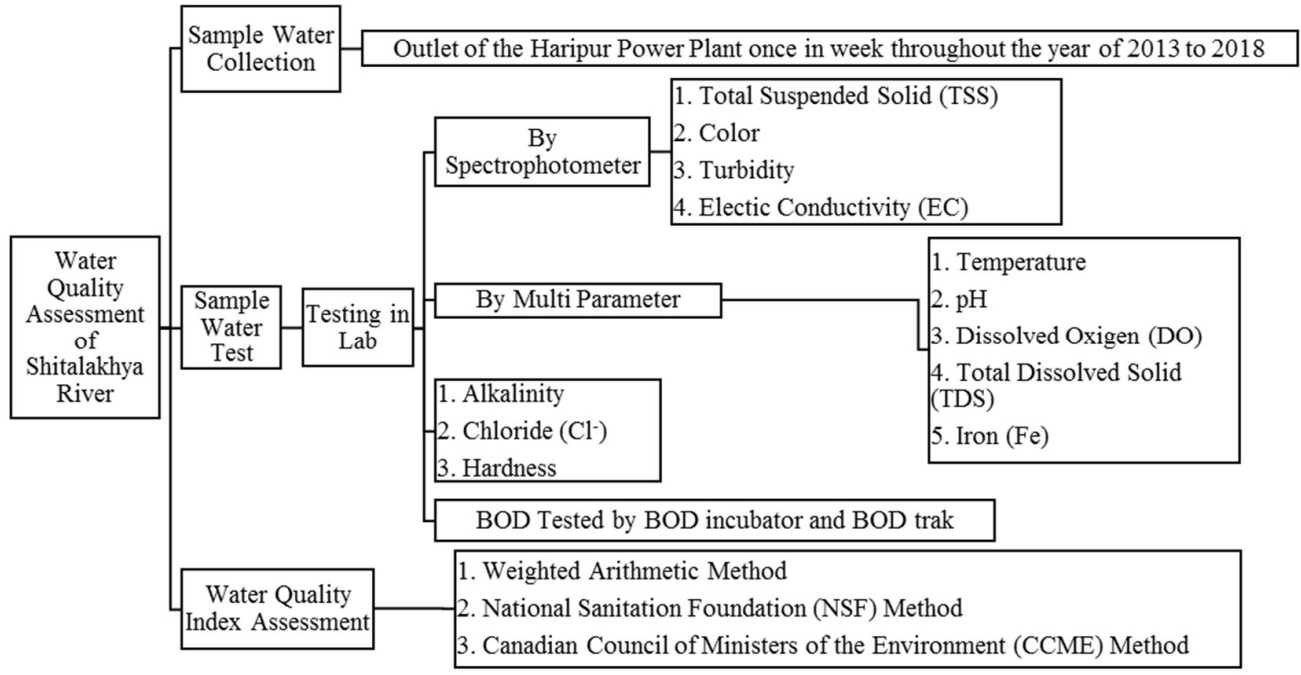

Figure 2: Methodological approach of the study.

Methodological flow chart of the study is shown in Figure 1.

\subsection{Weighted Arithmetic Water Quality Index Method}

The WQI, which is generated using the weighted arithmetic index algorithm (WAWQIM), is often utilized by academics in poor nations when data-gathering infrastructure is lacking and valid rating curves are few using the most routinely measured water quality variables, the weighted arithmetic water quality index approach categorized the water quality according to the degree of purity.

Various scientists have utilized the methodology extensively (Balan, Shivakumar\& Kumar, 2012) and the following equation was used to calculate the WQI (Brown, McClelland, Deininger\& O'Connor, 1972):

$$
W Q I=\frac{\sum Q_{i} W_{i}}{\sum W_{i}}
$$

This equation is used to compute the quality rating scale $\left(Q_{i}\right)$ for each parameter:

$$
Q_{i}=100\left[\left(V_{i}-V_{0} S_{i}-V_{0}\right)\right]
$$

Where,

$V_{i}$ is the $\mathrm{i}^{\text {th }}$ parameter's estimated concentration in the examined water.

In pure water, $V_{o}$ is the optimal value for this measure.

Except for $\mathrm{pH}=7.0$ and $\mathrm{DO}=14.6 \mathrm{mg} / 1, V_{o}=0$.

This parameter's suggested standard value is $S_{i}$. 
The following formula is used to compute the unit weight $\left(W_{i}\right)$ for each water quality measure:

Where,

$$
W_{i}=\frac{K}{S_{i}}
$$

$\mathrm{K}=$ The proportionality constant can alternatively be determined using the equation below:

$$
K=\frac{1}{\sum \frac{1}{S_{i}}} .
$$

Table 1 shows the water quality rating according to this WQI.

Table 1: Water quality rating as per weight arithmetic water quality index method.

\begin{tabular}{cc}
\hline WQI Value & Rating of Water Quality \\
\hline $0-25$ & Excellent water quality \\
$26-50$ & Good water quality \\
$51-75$ & Poor water quality \\
$76-100$ & Very Poor water quality \\
Above 100 & Unsuitable for drinking waterfor supply afterconventional treatment \\
\hline
\end{tabular}

\subsection{National Sanitation Foundation Water Quality Index (NSF WQI)}

A common water quality index technique was created by picking criteria with considerable care, constructing a standard scale, and allocating weights. The National Sanitation Foundation (NSF) backed the effort, which was dubbed NSFWQI to compute the WQI of numerous dangerously contaminated water bodies. $\mathrm{pH}$, Temperature, dissolved oxygen, turbidity, fecal coliform, biochemical oxygen demand, total phosphates, nitrates, and total solids are among the nine water quality characteristics used in the proposed method for comparing the water quality of multiple water sources (Brown, McClelland, Deininger\&Tozer, 1970).

The data on water quality is captured and transferred to a weighting curve chart, from which a numerical value of Qi is calculated. NSF WQI has the following mathematical expression:

$$
W Q I=\sum_{i=1}^{n} Q_{i} W_{i}
$$

Where

$Q_{i}$ is the $\mathrm{i}^{\text {th }}$ water quality parameter's sub-index.

$W_{i}$ denotes the weight assigned to each water quality metric.

The number of water quality parameters is denoted by the letter $n$.

The ratings of water quality for this NSFWQI method have been defined using the following Table 2:

Table 2: Water Quality Rating as per National Sanitation Foundation Water Quality Index method.

\begin{tabular}{cc}
\hline National Sanitation Foundation Method (NSF WQI) \\
\hline WQI Value & Rating of Water Quality \\
\hline $91-100$ & Excellent water quality \\
$71-90$ & Good water quality \\
$51-70$ & Medium water quality \\
$26-50$ & Bad water quality \\
$0-25$ & Very bad water quality \\
\hline
\end{tabular}

\subsection{Canadian Council of Ministers of the Environment Water Quality Index (CCME WQI)}

The CCME WQI is a standardized technique developed by Canadian jurisdictions to communicate water quality information to both managers and the general public. Moreover, WQI was created by a committee under the Canadian Council of Ministers of the Environment (CCME), and it may be used by many water authorities in other nations with minor modifications (Boyacioglu, 2010). This method was designed to assess surface water for aquatic life protection in compliance with particular requirements. The parameters associated with various measurements may differ from one station to the next, and the sampling technique calls for at least four 
parameters to be sampled four times (Khan, Tobin, Paterson, Khan, \& Warren, 2005) The following relationship can be used to calculate index scores in the CCME WQI method:

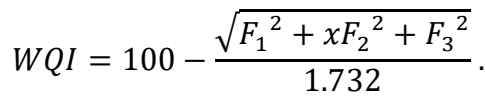

Where

Scope $\left(F_{1}\right)$ is the number of variables whose objectives have not been reached.

$\mathrm{F}_{1}=$ [Number of unsuccessful variables divided by the total number of variables]

Frequency $\left(\mathrm{F}_{2}\right)$ is the number of times the objectives are not reached out of a total of 100 .

$\mathrm{F}_{2}=$ [Number of failed tests divided by the total number of tests]

Amplitude $\left(\mathrm{F}_{3}\right)=$ The percentage of time that the objectives are not reached.

a) Excursioni $=[$ Failedtestvaluei /Objectivej $]-1$.

$$
\text { normalizedsumofexcursions, } \quad n s e=\frac{\sum_{i=1}^{n} \text { excursion }}{\text { No.ofTests }}
$$

b) $F_{3}=[\mathrm{nse} / 0.01 \mathrm{nse}+0.01]$

Five categories have been suggested to categorize the water qualities which are summarized in Table 3.

Table 3: Water quality rating as per Canadian Council of Ministers of the Environment Water Quality

\section{Canadian Council of Ministers of the Environment Water Quality Index (CCME WQI)}

\begin{tabular}{cc}
\hline WQI Value & Rating of Water Quality \\
\hline $95-100$ & Excellent water quality \\
$80-94$ & Good water quality \\
$60-79$ & Fairwater quality \\
$45-59$ & Marginal water quality \\
$0-44$ & Poor water quality \\
\hline
\end{tabular}

\section{RESULTS \& DISCUSSION}

\subsection{Assessment of Quality Using Different WQI Methods}

The Water Quality Index of the Shitalakshya River was estimated using three distinct methodologies in this study, including the Weighted Arithmetic Index Method, the Canadian Council of Ministers of the Environment Water Quality Index Method, and the National Sanitation Foundation Method. Table 4 shows the maximum, minimum, mean, variance, and standard deviation. The standard deviation and variance show that there is a lot of variation in the values of several metrics that affect the river's water quality. Table 5 illustrates the correlation matrix of water quality parameters.

Table 4: Maximum, minimum and average values of different water quality parameters.

\begin{tabular}{lcllllll}
\hline Parameter & Unit & $\begin{array}{l}\text { ECR-97 } \\
\text { (Standards) }\end{array}$ & $\begin{array}{l}\text { Maximum } \\
\text { Value }\end{array}$ & $\begin{array}{l}\text { Minimum } \\
\text { Value }\end{array}$ & $\begin{array}{l}\text { Mean } \\
\text { Value }\end{array}$ & Variance & $\begin{array}{l}\text { Standard } \\
\text { deviation }\end{array}$ \\
\hline $\mathrm{pH}$ & - & $6.5-8.5$ & 7.87 & 7.13 & 7.47 & 0.14 & 0.37 \\
$\mathrm{DO}$ & $\mathrm{mg} / \mathrm{l}$ & 6 & 5.87 & 0.23 & 2.88 & 0.48 & 0.69 \\
Color & $\mathrm{Pt}-\mathrm{co}$ & 15 & 52.50 & 2.73 & 20.27 & 4.72 & 2.17 \\
Conductivity & $\mu / \mathrm{c}$ & 550 & 1151.75 & 130.50 & 519.89 & 680.29 & 26.08 \\
TDS & $\mathrm{mg} / 1$ & 1000 & 637.25 & 64.40 & 277.45 & 1350.76 & 36.75 \\
TSS & $\mathrm{mg} / 1$ & 10 & 136.25 & 20.20 & 63.69 & 30.55 & 5.53 \\
Hardness & $\mathrm{mg} / 1$ & $200-500$ & 196.50 & 38.50 & 107.21 & 27.32 & 5.23
\end{tabular}




\begin{tabular}{lcllllll}
\hline Parameter & Unit & $\begin{array}{l}\text { ECR-97 } \\
\text { (Standards) }\end{array}$ & $\begin{array}{l}\text { Maximum } \\
\text { Value }\end{array}$ & $\begin{array}{l}\text { Minimum } \\
\text { Value }\end{array}$ & $\begin{array}{l}\text { Mean } \\
\text { Value }\end{array}$ & Variance & $\begin{array}{l}\text { Standard } \\
\text { deviation }\end{array}$ \\
\hline $\mathrm{Cl}^{-}$ & $\mathrm{mg} / 1$ & $150-600$ & 147.50 & 9.20 & 50.72 & 141.87 & 11.91 \\
Turbidity & $\mathrm{ftu}$ & 10 & 146.50 & 17.60 & 50.57 & 37.03 & 6.08 \\
Alkalinity & $\mathrm{mg} / 1$ & 128 & 450.00 & 35.20 & 170.08 & 606.98 & 24.64 \\
$\mathrm{Fe}$ & $\mathrm{mg} / 1$ & $0.3-1.0$ & 10.25 & 0.02 & 0.52 & 0.12 & 0.34 \\
Temperature & ${ }^{\circ} \mathrm{C}$ & $20-30$ & 32.08 & 21.20 & 28.20 & 1.26 & 1.12 \\
$\mathrm{BOD}$ & $\mathrm{mg} / 1$ & 0.2 & 6.5 & 2.8 & 4.9 & 0.18 & 0.42 \\
\hline
\end{tabular}

The Environment Conservation Rules, 1997 (ECR-97) establish numerous conditions for acceptable water. ECR-97's standard value is shown in Table-4. The tested water quality parameters were then compared to the standard values to determine the existence of being within the limit.

Table 4 shows that the ECR-97 standards for $\mathrm{pH}$ and temperature were satisfied. The average $\mathrm{pH}$ is 7.47 , with the ECR-97 norm ranging from 6.5 to 8.5. Although the maximum temperature was $32.08^{\circ} \mathrm{C}$ and the usual temperature is $20-30^{\circ} \mathrm{C}$, the average water temperature was measured to be $28.20^{\circ} \mathrm{C}$. The ECR-97 water hardness limits range from 200 to $500 \mathrm{mg} / 1$, and this study found a mean value of $107.21 \mathrm{mg} / 1$, which is near the limit. Color, TSS, and BOD levels were substantially high in comparison, whereas DO rates were significantly lower than the normal threshold.

In addition, The variation and standard deviation (SD) of numerous water quality indices are shown in Table 4. Simply explained, variance is a measure of the dispersion of numbers concerning their average value. The standard deviation, on the other hand, is the degree of variance or dispersion of a collection of numbers. Variance and standard deviation are used to determine whether or not a parameter remains consistent throughout the year. The $\mathrm{pH}, \mathrm{DO}$, temperature, and BOD variance readings were found to be near zero in this investigation. This indicates that these characteristics are rather consistent throughout the year. However, conductivity, TDS, and alkalinity all show extraordinarily high variation values, indicating that these parameters fluctuate over time or are impacted by other factors.

Table 5: Correlation matrix of water quality parameters of Shitalakshya River.

\begin{tabular}{|c|c|c|c|c|c|c|c|c|c|c|c|c|c|}
\hline & II & $\cong$ & $\frac{\dot{0}}{0}$ & 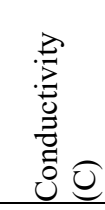 & $\tilde{\rho}$ & 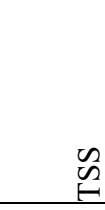 & 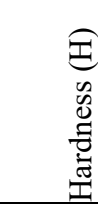 & $\frac{1}{0}$ & 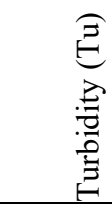 & 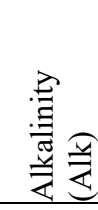 & $\begin{array}{l}0 \\
0 \\
0 \\
0\end{array}$ & 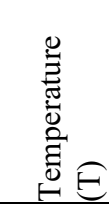 & Оิ \\
\hline $\mathrm{pH}$ & 1 & & & & & & & & & & & & \\
\hline DO & 0.84 & 1 & & & & & & & & & & & \\
\hline Color & 0.13 & -0.03 & 1 & & & & & & & & & & \\
\hline $\mathrm{C}$ & 0.32 & -0.05 & 0.43 & 1 & & & & & & & & & \\
\hline TDS & 0.26 & 0.15 & 0.12 & 0.84 & 1 & & & & & & & & \\
\hline TSS & 0.11 & 0.41 & 0.36 & -0.60 & -0.58 & 1 & & & & & & & \\
\hline $\mathrm{H}$ & 0.35 & 0.17 & 0.92 & 0.60 & 0.38 & 0.25 & 1 & & & & & & \\
\hline $\mathrm{Cl}^{-}$ & -0.24 & -0.25 & 0.01 & 0.65 & 0.84 & -0.67 & 0.09 & 1 & & & & & \\
\hline $\mathrm{Tu}$ & -0.05 & 0.12 & 0.76 & 0.04 & 0.05 & 0.65 & 0.76 & -0.06 & 1 & & & & \\
\hline Alk & -0.38 & -0.73 & 0.06 & 0.65 & 0.48 & -0.82 & 0.10 & 0.61 & -0.23 & 1 & & & \\
\hline $\mathrm{Fe}$ & -0.08 & -0.13 & 0.95 & 0.39 & 0.18 & 0.34 & 0.83 & 0.20 & 0.80 & 0.09 & 1 & & \\
\hline $\mathrm{T}$ & 0.47 & 0.47 & -0.19 & 0.09 & 0.27 & 0.03 & 0.17 & -0.19 & 0.11 & -0.10 & -0.34 & 1 & \\
\hline BOD & -0.60 & -0.37 & -0.78 & -0.48 & -0.24 & -0.32 & -0.92 & 0.20 & -0.62 & 0.06 & -0.59 & -0.40 & 1 \\
\hline
\end{tabular}




\subsubsection{WQI by Weighted Arithmetic Method}

The water quality of the river might also fluctuate due to seasonal variations. The number of water quality factors changes as the weather changes. Variations in sunlight, dissolved oxygen, water temperature, and other factors may induce variations in water quality over sessions.

To determine the WQI by Weighted Arithmetic Method (WAM), the sub-water quality index for various parameters was estimated. The bar chart (Figure 3) compares the seasonal water quality index values for different years. It was found most of the water quality parameters exceed the permissible limit throughout the year. The worst scenario was visible in the post-monsoon season for most of the year. However, water quality parameters were slightly better in the monsoon period which eventually made the index value barely within the limit to be considered as good water quality. According to the rating of arithmetic index value (Table-1), only the monsoon season of 2018 showed good water quality.

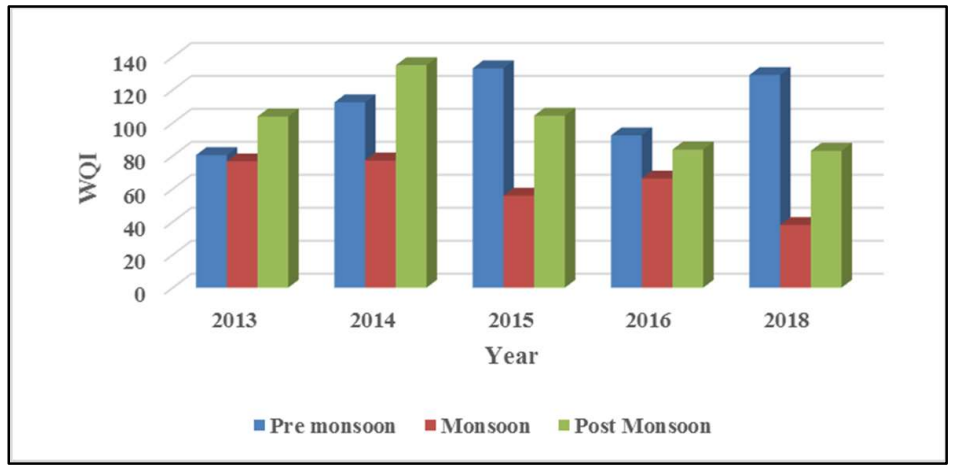

Figure 3: Seasonal variation in the WQI determined by weight arithmetic method.

The bar chart contrasts the seasonal water quality index method for several years as determined by the Weighted Arithmetic Method. Throughout the year, most of the water quality metrics were determined to be over permitted levels.According to the arithmetic method, the value of WQI must be as low as feasible to be considered drinking water quality; nevertheless, as the value of WQI rises, the quality will deteriorate from poor to poorer. The method states that when the value of WQI exceeds 100 , the water quality will be unsuitable for drinking water supply after conventional treatment, and the figure demonstrates that the value of WQI surpasses 100 in most of the seasons of most of the years. The average value is likewise more than 80 . Whereas the worstcase scenario was observable for the majority of the year in the post-monsoon season.However, water quality metrics were marginally improved during the monsoon period (2018), resulting in an index value that was just under the limit to be called satisfactory water quality.

\subsubsection{WQI by NSF}

Figure 4 shows the seasonal variation in water quality for the different years by the NSF method. According to the NSF method the water quality is degrading along with time. Among the 5 different years, the scenario was awful for the year 2018 almost throughout the year.

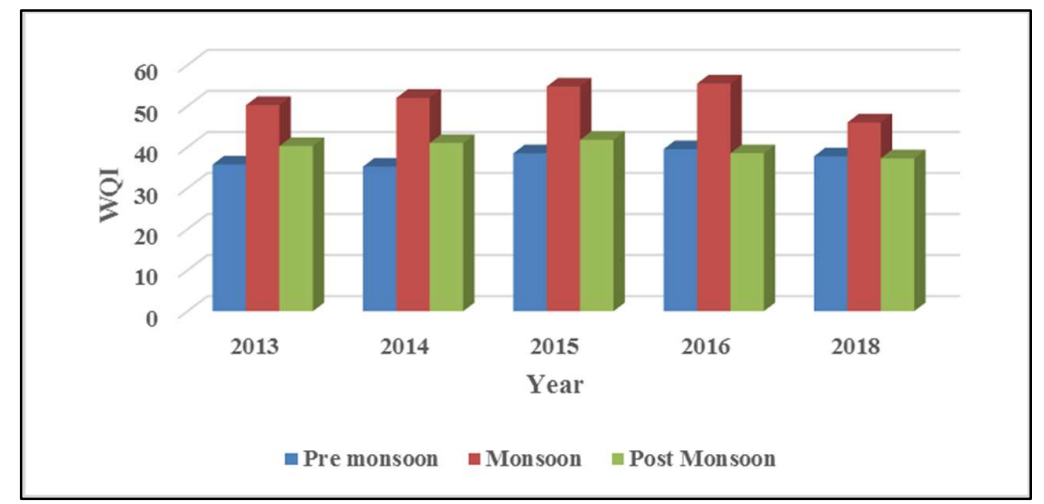

Figure 4: Seasonal variation in the WQI determined by National Sanitation Foundation Water Quality Index (NSF) method. 
As per the NSF method, the value of WQI must be as high as possible to be called drinking water quality; however, as the value of WQI lowers, the quality deteriorates from bad to worse. According to the method, when the WQI number falls below 25, the water quality is very poor. The NSF standard, which defines water quality as 'Bad water quality,' was used in the study to determine the value of WQI between 30-50.

\subsubsection{WQI by CCME}

Following Table 6 shows the calculation of factors for the CCME method for the year 2018. It was found mostly there were three to seven parameters among the twelve parameters which were failed to be within the permissible limit. For the particular year, April was the month which falls within pre-monsoon experienced the poorest quality. According to the following method, $\mathrm{F}_{2}$ expresses the fact that mostly the parameters were far away from the standard values in post-monsoon.

Table 6: Results of WQI founded by CCEM method.

\begin{tabular}{ccccccccccc}
\hline Month & $\begin{array}{c}\text { Failed } \\
\text { Item }\end{array}$ & $\begin{array}{c}\text { Total } \\
\text { Item }\end{array}$ & F $_{1}$ & $\begin{array}{c}\text { No. of } \\
\text { Failed } \\
\text { test }\end{array}$ & $\begin{array}{c}\text { Total } \\
\text { test }\end{array}$ & F $_{2}$ & $\begin{array}{c}\text { Total } \\
\text { Excursion }\end{array}$ & nse & F $_{3}$ & CCME WQI \\
\hline JAN & 5 & 13 & 38.46 & 23 & 55 & 41.8 & 87.57 & 1.59 & 100.01 & 12.60 \\
FEB & 5 & 13 & 38.46 & 20 & 44 & 45.5 & 102.13 & 2.32 & 100.01 & 11.56 \\
MAR & 5 & 13 & 38.46 & 20 & 44 & 45.5 & 159.91 & 3.63 & 100.01 & 11.56 \\
APR & 7 & 13 & 53.85 & 21 & 44 & 47.7 & 135.10 & 3.07 & 100.01 & 6.38 \\
MAY & 3 & 13 & 23.08 & 12 & 44 & 27.3 & 21.23 & 0.48 & 100.01 & 19.30 \\
JUN & 3 & 13 & 23.08 & 9 & 33 & 27.3 & 14.58 & 0.44 & 100.01 & 19.30 \\
JUL & 6 & 13 & 46.15 & 19 & 47 & 40.4 & 42.95 & 0.91 & 100.01 & 10.85 \\
AUG & 4 & 13 & 30.77 & 16 & 44 & 36.4 & 54.45 & 1.24 & 100.01 & 15.83 \\
SEP & 5 & 13 & 38.46 & 17 & 47 & 36.2 & 59.14 & 1.26 & 100.01 & 14.07 \\
OCT & 5 & 13 & 38.46 & 18 & 47 & 38.3 & 27.67 & 0.59 & 100.01 & 13.54 \\
NOV & 6 & 13 & 46.15 & 20 & 45 & 44.4 & 61.81 & 1.37 & 100.01 & 9.75 \\
DEC & 6 & 13 & 46.15 & 22 & 46 & 47.8 & 85.11 & 1.85 & 100.01 & 8.76 \\
\hline
\end{tabular}

In this table, it has been noticed that in the monsoon period number of failures is respectively low, on the other hand in pre-monsoon and post-monsoon the number of failures is high.

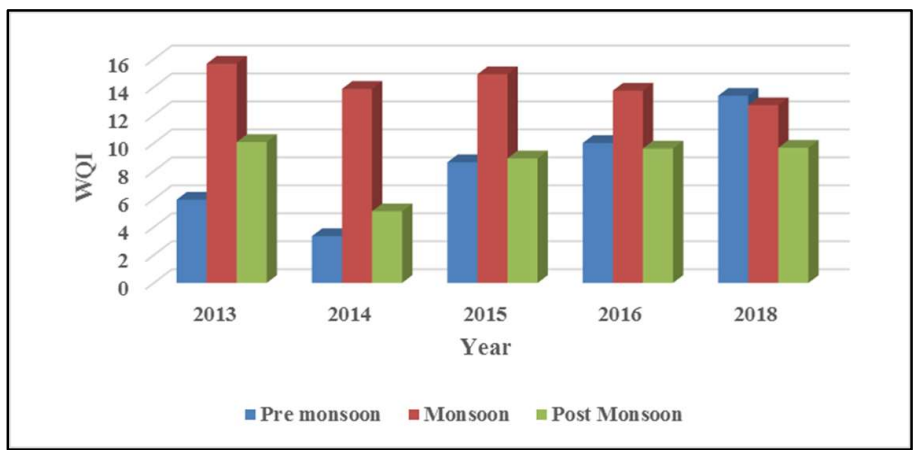

Figure 5: Seasonal variation in the WQI determined by the Canadian Council of Ministers of the Environment Water Quality Index (CCME) method.

Figure 5 compares the result for different seasons using the CCME method. For the year 2014, the pre-monsoon season was awful according to Table 3.According to the CCME method, the value of WQI must be as high as achievable to be referred to as drinking water quality; unfortunately, as the value of WQI declines, the quality deteriorates from bad to worse. When the WQI value goes below 44, the water quality is considered very poor, 
according to the technique. In the study, the CCME technique, which defines water quality as "Bad water quality," was utilized to calculate the value of WQI less than 16.

\subsection{Comparison of WQI between different methods}

Table-7 compares the seasonal water quality index method for different years for different methods. There was almost no variation among the three different methods for assessing water quality index values. The water quality of the specific river water was found to be unsatisfactory for household, drinking, and aquatic species in practically every season and every technique. However, rendering the method WAI, the quality showed good whereas for the same season other two methods showed the opposite result.

Table 7: WQI value for the period of 2013-2018 according to different methods considering the corresponding rating.

\begin{tabular}{|c|c|c|c|c|c|c|c|c|c|c|c|}
\hline & & 2013 & & 2014 & & 2015 & & 2016 & & 2018 & \\
\hline $\begin{array}{l}\overline{\bar{g}} \\
\bar{\partial} \\
z^{\frac{E}{0}}\end{array}$ & 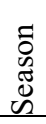 & $\begin{array}{l}\text { WQI } \\
\text { Valu } \\
\mathrm{e} \\
\end{array}$ & $\begin{array}{l}\text { WQI } \\
\text { Rating }\end{array}$ & $\begin{array}{l}\text { WQI } \\
\text { Valu } \\
\mathrm{e} \\
\end{array}$ & $\begin{array}{l}\text { WQI } \\
\text { Rating }\end{array}$ & $\begin{array}{l}\text { WQI } \\
\text { Valu } \\
\mathrm{e} \\
\end{array}$ & $\begin{array}{l}\text { WQI } \\
\text { Rating }\end{array}$ & $\begin{array}{l}\text { WQI } \\
\text { Value }\end{array}$ & $\begin{array}{l}\text { WQI } \\
\text { Rating }\end{array}$ & $\begin{array}{l}\text { WQI } \\
\text { Valu } \\
\mathrm{e}\end{array}$ & $\begin{array}{l}\text { WQI } \\
\text { Rating }\end{array}$ \\
\hline & 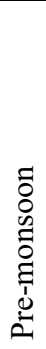 & 80 & $\begin{array}{l}\text { Very } \\
\text { Poor } \\
\text { water } \\
\text { quality }\end{array}$ & 112 & $\begin{array}{l}\text { Unsuitabl } \\
\text { e for } \\
\text { drinking } \\
\text { water for } \\
\text { supply } \\
\text { after } \\
\text { conventio } \\
\text { nal } \\
\text { treatment }\end{array}$ & 133 & $\begin{array}{l}\text { Unsuitab } \\
\text { le for } \\
\text { drinking } \\
\text { water for } \\
\text { supply } \\
\text { after } \\
\text { conventi } \\
\text { onal } \\
\text { treatment }\end{array}$ & 92 & $\begin{array}{l}\text { Very } \\
\text { Poor } \\
\text { water } \\
\text { quality }\end{array}$ & 151 & $\begin{array}{l}\text { Unsuitable } \\
\text { for } \\
\text { drinking } \\
\text { water for } \\
\text { supply after } \\
\text { convention } \\
\text { al treatment }\end{array}$ \\
\hline & $\begin{array}{l}5 \\
0 \\
0 \\
0 \\
0 \\
\Sigma\end{array}$ & 77 & $\begin{array}{l}\text { Very } \\
\text { Poor } \\
\text { water } \\
\text { quality }\end{array}$ & 77 & $\begin{array}{l}\text { Very Poor } \\
\text { water } \\
\text { quality }\end{array}$ & 56 & $\begin{array}{l}\text { Poor } \\
\text { water } \\
\text { quality }\end{array}$ & 66 & $\begin{array}{l}\text { Poor } \\
\text { water } \\
\text { quality }\end{array}$ & 87 & $\begin{array}{l}\text { Good water } \\
\text { quality }\end{array}$ \\
\hline$\frac{Z}{3}$ & $\begin{array}{l}\tilde{\delta} \\
0 \\
0 \\
0 \\
0 \\
\sum^{0} \\
0 \\
0\end{array}$ & 104 & $\begin{array}{l}\text { Unsuitab } \\
\text { le for } \\
\text { drinking } \\
\text { water for } \\
\text { supply } \\
\text { after } \\
\text { conventi } \\
\text { onal } \\
\text { treatment }\end{array}$ & 286 & $\begin{array}{l}\text { Unsuitabl } \\
\text { e for } \\
\text { drinking } \\
\text { water for } \\
\text { supply } \\
\text { after } \\
\text { conventio } \\
\text { nal } \\
\text { treatment }\end{array}$ & 104 & $\begin{array}{l}\text { Unsuitab } \\
\text { le for } \\
\text { drinking } \\
\text { water for } \\
\text { supply } \\
\text { after } \\
\text { conventi } \\
\text { onal } \\
\text { treatment }\end{array}$ & 84 & $\begin{array}{l}\text { Very } \\
\text { Poor } \\
\text { water } \\
\text { quality }\end{array}$ & 108 & $\begin{array}{l}\text { Poor water } \\
\text { quality }\end{array}$ \\
\hline & $\begin{array}{l}\tilde{\delta} \\
0 \\
0 \\
0 \\
0 \\
\vdots \\
0 \\
0 \\
0\end{array}$ & 6 & $\begin{array}{l}\text { Poor } \\
\text { water } \\
\text { quality }\end{array}$ & 3 & $\begin{array}{l}\text { Poor } \\
\text { water } \\
\text { quality }\end{array}$ & 9 & $\begin{array}{l}\text { Poor } \\
\text { water } \\
\text { quality }\end{array}$ & 10 & $\begin{array}{l}\text { Poor } \\
\text { water } \\
\text { quality }\end{array}$ & 13 & $\begin{array}{l}\text { Poor water } \\
\text { quality }\end{array}$ \\
\hline & $\begin{array}{l}0 \\
0 \\
0 \\
0 \\
0 \\
\Sigma\end{array}$ & 16 & $\begin{array}{l}\text { Poor } \\
\text { water } \\
\text { quality }\end{array}$ & 14 & $\begin{array}{l}\text { Poor } \\
\text { water } \\
\text { quality }\end{array}$ & 15 & $\begin{array}{l}\text { Poor } \\
\text { water } \\
\text { quality }\end{array}$ & 14 & $\begin{array}{l}\text { Poor } \\
\text { water } \\
\text { quality }\end{array}$ & 13 & $\begin{array}{l}\text { Poor water } \\
\text { quality }\end{array}$ \\
\hline$\sum_{U}^{\Perp}$ & $\begin{array}{l}0 \\
0 \\
0 \\
0 \\
0 \\
0 \\
0\end{array}$ & 10 & $\begin{array}{l}\text { Poor } \\
\text { water } \\
\text { quality }\end{array}$ & 5 & $\begin{array}{l}\text { Poor } \\
\text { water } \\
\text { quality }\end{array}$ & 9 & $\begin{array}{l}\text { Poor } \\
\text { water } \\
\text { quality }\end{array}$ & 10 & $\begin{array}{l}\text { Poor } \\
\text { water } \\
\text { quality }\end{array}$ & 10 & $\begin{array}{l}\text { Poor water } \\
\text { quality }\end{array}$ \\
\hline $\begin{array}{l}\text { 岁 } \\
\text { 乙 }\end{array}$ & $\begin{array}{l}\tilde{\delta} \\
0 \\
0 \\
0 \\
0 \\
\Xi \\
D \\
D \\
0\end{array}$ & 36 & $\begin{array}{l}\text { Bad } \\
\text { water } \\
\text { quality }\end{array}$ & 35 & $\begin{array}{l}\text { Bad water } \\
\text { quality }\end{array}$ & 39 & $\begin{array}{l}\text { Bad } \\
\text { water } \\
\text { quality }\end{array}$ & 40 & $\begin{array}{l}\text { Bad } \\
\text { water } \\
\text { quality }\end{array}$ & 38 & $\begin{array}{l}\text { Bad water } \\
\text { quality }\end{array}$ \\
\hline
\end{tabular}




\begin{tabular}{|c|c|c|c|c|c|c|c|c|c|c|c|}
\hline \multirow{4}{*}{$\begin{array}{l}\bar{E} \\
\bar{O} \\
\sum^{\frac{E}{0}}\end{array}$} & \multirow[b]{2}{*}{$\begin{array}{l}\tilde{0} \\
\text { है } \\
\tilde{D} \\
\tilde{n}\end{array}$} & \multicolumn{2}{|l|}{2013} & \multicolumn{2}{|l|}{2014} & \multicolumn{2}{|l|}{2015} & \multicolumn{2}{|l|}{2016} & \multicolumn{2}{|l|}{2018} \\
\hline & & $\begin{array}{l}\text { WQI } \\
\text { Valu } \\
\mathrm{e} \\
\end{array}$ & $\begin{array}{l}\text { WQI } \\
\text { Rating }\end{array}$ & $\begin{array}{l}\text { WQI } \\
\text { Valu } \\
\mathrm{e} \\
\end{array}$ & $\begin{array}{l}\text { WQI } \\
\text { Rating }\end{array}$ & $\begin{array}{l}\text { WQI } \\
\text { Valu } \\
\mathrm{e} \\
\end{array}$ & $\begin{array}{l}\text { WQI } \\
\text { Rating }\end{array}$ & $\begin{array}{l}\text { WQI } \\
\text { Value }\end{array}$ & $\begin{array}{l}\text { WQI } \\
\text { Rating }\end{array}$ & $\begin{array}{l}\text { WQI } \\
\text { Valu } \\
\mathrm{e} \\
\end{array}$ & $\begin{array}{l}\text { WQI } \\
\text { Rating }\end{array}$ \\
\hline & $\begin{array}{l}5 \\
8 \\
0 \\
0 \\
0 \\
\Sigma\end{array}$ & 50 & $\begin{array}{l}\text { Bad } \\
\text { water } \\
\text { quality }\end{array}$ & 52 & $\begin{array}{l}\text { Medium } \\
\text { water } \\
\text { quality }\end{array}$ & 55 & $\begin{array}{l}\text { Medium } \\
\text { water } \\
\text { quality }\end{array}$ & 56 & $\begin{array}{l}\text { Mediu } \\
\mathrm{m} \\
\text { water } \\
\text { quality }\end{array}$ & 46 & $\begin{array}{l}\text { Bad water } \\
\text { quality }\end{array}$ \\
\hline & $\begin{array}{l}\tilde{0} \\
0 \\
0 \\
0 \\
\sum_{0}^{0} \\
0 \\
0\end{array}$ & 40 & $\begin{array}{l}\text { Bad } \\
\text { water } \\
\text { quality }\end{array}$ & 41 & $\begin{array}{l}\text { Bad water } \\
\text { quality }\end{array}$ & 42 & $\begin{array}{l}\text { Bad } \\
\text { water } \\
\text { quality }\end{array}$ & 39 & $\begin{array}{l}\text { Bad } \\
\text { water } \\
\text { quality }\end{array}$ & 37 & $\begin{array}{l}\text { Bad water } \\
\text { quality }\end{array}$ \\
\hline
\end{tabular}

\section{CONCLUSIONS}

In this study, the samples were collected from the Shitalakshya River once a week at the outlet point of the Haripur power plant throughout the year. Assessment of Shitalkhya river water quality was done for the past five years (January 2013 to December 2018). The comparison was shown considering different seasons; Premonsoon, Monsoon, Post monsoon. Water quality parameters such as $\mathrm{pH}, \mathrm{DO}, \mathrm{BOD}, \mathrm{EC}$, color, turbidity, hardness and some minerals were examined for the evaluation. The main purpose of the research work was to assess the water quality utilizing different water quality index methods; Three widely used methods; (WAI method, NSF method, CCME method) were used to calculate the WQI. This type of surface water rating might aid individuals in having a clear grasp of the water quality state to make better decisions about its future use. Besides, WQI combines the combined effects of many water quality metrics and disseminates water quality data to the general public and legislative decision-makers. After assessing the results, the study reveals that the quality of the Shitalakshya River possesses poor water quality. The results were similar for the three different methods which proved the validity of the result. Moreover, the water quality status was almost similar throughout the year regardless of seasonal variation. Among the different parameters, mostly turbidity, electrical conductivity, TSS, Iron were the parameters that caused the situation worst. This will eventually affect the aquatic ecosystems, recreational and industrial use. Consequently, fish culture has been defused due to this condition. Furthermore, the cost of treatment of water to be used in industries is dramatically increasing. Indirectly, therefore, the worst quality of surface water helps to increase the cost of production and to affect the economy of the country.

\section{ACKNOWLEDGEMENTS}

Foremost, we would like to express our sincere gratitude towards Habibur Rahman, Chemist, New Haripur,412 MW CCPP, EGCB LTD for the continuous support for this research work. His guidance helped us all the time for all sorts of analysis. This is to declare that a part of this paper has been presented in ICCESD 2020 conference.

\section{REFERENCES}

Balan, I. N., Shivakumar, M., \& Kumar, P. D. (2012).An assessment of groundwater quality using water quality index in Chennai, Tamil Nadu, India. Chronicles of young scientists, 3(2).

Boyacioglu, H. (2010). Utilization of the water quality index method as a classification tool. Environmental monitoring and assessment, 167(1), 115-124.

Brown, R. M., McClelland, N. I., Deininger, R. A., \&Tozer, R. G. (1970). A water quality index-do we dare. Water and sewage works, 117(10).

Brown, R. M., McClelland, N. I., Deininger, R. A., \& O’Connor, M. F. (1972).A water quality index-crashing the psychological barrier.In Indicators of environmental quality (pp. 173-182).Springer, Boston, MA.

Chowdhury, R. M., Muntasir, S. Y., \&Hossain, M. M. (2012).Water quality index of water bodies along Faridpur-Barisal road in Bangladesh. Glob Eng Tech Rev, 2(3), 1-8.

Goyette, J. O., Bennett, E. M., Howarth, R. W., \&Maranger, R. (2016). Changes in anthropogenic nitrogen and phosphorus inputs to the St. Lawrence sub-basin over 110 years and impacts on riverine export. Global Biogeochemical Cycles, 30(7), 1000-1014. 
Khan, A. A., Tobin, A., Paterson, R., Khan, H., \& Warren, R. (2005).Application of CCME procedures for deriving site-specific water quality guidelines for the CCME Water Quality Index. Water Quality Research Journal, 40(4), 448-456.

Oni, O., \&Fasakin, O. (2016).The use of water quality index method to determine the potability of surface water and groundwater in the vicinity of a municipal solid waste dumpsite in Nigeria. American Journal of Engineering Research (AJER), 5(10), 96-101.

Pal, M., Ayele, Y., Hadush, M., Panigrahi, S., \&Jadhav, V. J. (2018). Public health hazards due to unsafe drinking water. Air Water Borne Dis, 7(1000138), 2.

Sahu, P., \&Sikdar, P. K. (2008).Hydrochemical framework of the aquifer in and around East Kolkata Wetlands, West Bengal, India. Environmental Geology, 55(4), 823-835.

Weeks, J. R. (2020). Population: An introduction to concepts and issues. Cengage Learning.

World Health Organization,\&ŚwiatowaOrganizacjaZdrowia. (2004). World report on knowledge for better health: strengthening health systems. World Health Organization.

(C) 2021 the JES.Journal of Engineering Science published by Faculty of Civil Engineering, Khulna University of Engineering \& Technology. This is an open access article under the terms of the Creative Commons AttributionNonCommercial-NoDerivatives License, which permits use and distribution in any medium, provided the original work is properly cited, the use is non-commercial and no Modifications or adaptations are made. 